\title{
Clinical significance of immune cell infiltration within gallbladder
}

\section{cancer}

\author{
Y Nakakubo',3, M Miyamoto*, ',3, Y Cho', Y Hida', T Oshikiri', M Suzuoki', K Hiraoka', T Itoh'2, S Kondo' and \\ H Katoh'
}

'Department of Surgical Oncology, Division of Cancer Medicine, Hokkaido University, Graduate School of Medicine, N-I 5 W-7, Kita-ku,

Sapporo 060-8638, Japan; ${ }^{2}$ Department of Pathology, Hokkaido University Hospital, N-I 4 W-5, Kita-ku, Sapporo 060-8648, Japan

To investigate the pathophysiological significance of infiltrating antitumour immune cells, we evaluated the quantity of immune cell intratumoral infiltration in 110 surgically resected gallbladder specimens by immunohistochemistry. We examined 45 cases of gallbladder cancer and 65 cases of benign gallbladder diseases for $\mathrm{CD} 4^{+} \mathrm{T}$ cells, $\mathrm{CD} 8^{+} \mathrm{T}$ cells, natural killer cells (NKCs), and dendritic cells (DCs). High levels of CD4 ${ }^{+}{ }^{T}$ cell, $C D 8^{+}{ }^{+}$cell, NKC, and DC infiltration were recognised in $51.1 \%$ (23 out of 45), $37.8 \%$ ( 17 out of 45 ), 33.3\% ( 15 out of 45 ), and $48.9 \%$ (22 out of 45 ) of cancer specimens, respectively. High numbers of infiltrating $\mathrm{CD}^{+}$and $\mathrm{CD}^{+}{ }^{+} \mathrm{T}$ cells correlated with decreasing tumour invasion, and high numbers of infiltrating DCs correlated with decreasing lymph-node tumour metastasis. Furthermore, increased infiltration of $\mathrm{CD} 4^{+}$and $\mathrm{CD} 8^{+} \mathrm{T}$ cells and DCs exhibited a significant correlation with prolonged survival. NKC infiltration, however, did not correlate with any of the clinicopathological factors examined. Additionally, high levels of infiltration were not identified in specimens from benign diseases, consistent with the cancerspecific activity of $\mathrm{CD} 4^{+}$and $\mathrm{CD} 8^{+} \mathrm{T}$ cells and $\mathrm{DCs}$. In this study, we demonstrate that $\mathrm{CD} 4^{+}$and $\mathrm{CD} 8^{+}$tumour-infiltrating lymphocyte and DCs, but not NKCs, are important factors in the accurate prognosis of survival after surgical removal of gallbladder adenocarcinoma.

British Journal of Cancer (2003) 89, 1736 - 1742. doi: I0. I038/sj.bjc.660 I33। www.bjcancer.com

(C) 2003 Cancer Research UK

Keywords: CD4; CD8; natural killer cells (NKCs); dendritic cells (DCs); gallbladder cancer, immunohistochemistry

The prognosis for patients with gallbladder cancer remains poor despite improved diagnostic methods and surgical techniques. The 5 -year survival rate after surgery is less than $15 \%$ (Donohue et al, 1990; Gall et al, 1991; Oertli et al, 1993; Cubertafond et al, 1994; Ruckert et al, 1996). The prognostic factors for gallbladder cancer are lymph-node metastases and the local extent of the primary tumour, which significantly influence surgical course and determine the prognosis after surgery (Tsukada et al, 1997; Sugawara et al, 1999). Recently, molecular biological studies have reported that specific cancer-derived proteins are associated with progression and prognosis in gallbladder cancer (Hui et al, 2000; Shi et al, 2000; Kawamoto et al, 2001; Quan et al, 2001).

Both tumour-specific and nonspecific lymphocytes play an important role in antitumour immune responses, through tumour recognition and immunological elimination of local and metastatic tumour cells (Boon et al, 1994; Brandle et al, 1996; Whiteside and Herberman, 1995; Tanaka et al, 1997).

A single malignant cell may have multiple tumour-specific antigens (Wortzel et al, 1983; Knuth et al, 1989; Van den Eynde et al, 1989). Cytotoxic $\mathrm{CD}^{+} \mathrm{T}$ cells recognise MHC class I molecules bearing antigenic peptides derived from endogenously synthesised proteins (Larsson et al, 2001). As the majority of tumours express $\mathrm{MHC}$ class $\mathrm{I}, \mathrm{CD}^{+} \mathrm{T}$ cells can directly lyse

*Correspondence: Dr M Miyamoto;

E-mail: m-miyamo@med.hokudai.ac.jp

${ }^{3}$ Both authors contributed equally to this work.

Received 2 December 2002; revised 4 July 2003; accepted 3I July 2003 tumour cells and destroy large tumour masses in vivo (Wang, 2001). In contrast to $\mathrm{CD}^{+} \mathrm{T}$ cells, $\mathrm{CD}^{+}{ }^{+} \mathrm{T}$ cells recognise tumour-specific antigenic peptides on MHC class II molecules via an exogenous processing pathway (Larsson et al, 2001). Cytokines, such as IL-2 or IFN-gamma, released by $\mathrm{CD}^{+}{ }^{+} \mathrm{T}$ cells upon antigenic stimulation are important for the antitumour effects of activated $\mathrm{CD} 4{ }^{+} \mathrm{T}$ cells in vivo (Mumberg et al, 1999; Marzo et al, 2000; Beatty and Paterson, 2001). Activation of both T-cell subsets requires the presentation of antigenic peptides on professional antigen-presenting cells (APCs) (Larsson et al, 2001). Dendritic cells (DCs), the most potent APCs, play a central role in antitumour immunity by engulfing tumour antigens to facilitate the stimulation of antigen-specific T cells (Lespagnard et al, 1999; Almand et al, 2000). Natural killer cells (NKCs), comprising approximately $15 \%$ of all circulating lymphocytes, are a component of the innate immune system with the ability to lyse tumour cells and to provide early sources of immunoregulatory cytokines (Cooper et al, 2001).

Multiple immunohistochemical studies have described the relationship between immune-cell infiltration and tumour progression or prognosis in several cancers (Naito et al, 1998; Lespagnard et al, 1999; Ishigami et al, 2000a, b; Nakano et al, 2001; Schumacher et al, 2001). These studies have formed the basis for the practical application of immunotherapy (Malone et al, 2001; Valone et al, 2001; Ying et al, 2001; Barnea et al, 2002; Dhodapkar et al, 2002). The clinicopathological significance of infiltrating antitumour immune cells within gallbladder adenocarcinomas, however, has not been clarified. 
We sought to determine the relationship of the intratumoural infiltration of $\mathrm{CD}^{+}{ }^{+} \mathrm{T}$ cells, $\mathrm{CD} 8^{+} \mathrm{T}$ cells, NKCs, and DCs with tumour progression to identify favourable prognostic factors for patients with adenocarcinoma of the gallbladder.

\section{MATERIALS AND METHODS}

\section{Patients}

Between 1989 and 1999, we obtained samples from 110 gallbladders resected in the Department of Surgical Oncology, Division of Cancer Medicine at the Hokkaido University Graduate School of Medicine and affiliated hospitals. In every case, informed consent was obtained from the subject and guardian. In all, 45 cases were diagnosed as primary gallbladder adenocarcinoma (17 males and 28 females with a mean age of 66.7 years). No distant metastases were detected at preoperative examination. The clinical typing of tumours was performed according to the guidelines of the TNM Classification of Malignant Tumours (International Union Against Cancer, 1997). Nine tumours were classified as Stage I, 15 as Stage II, 5 as Stage III, and 16 as Stage IV.

Standard clinical treatment for advanced gallbladder cancer comprised removal of the gallbladder, wedge resection of the liver, resection of the extrahepatic bile duct, and resection of the regional lymph nodes. If the primary tumour or metastatic lymph nodes involve adjacent organs, including the head of the pancreas, duodenum, or colon, additional extended surgery to remove the affected area through pancreaticoduodenectomy, major hepatectomy, or colectomy was employed. Simple cholecystectomy was performed for early gallbladder cancer.

Benign diseases of the gallbladder included 20 cases of cholecystitis without anomalous pancreaticobiliary ductal junction (APBDJ), 24 cases of cholecystitis with APBDJ, 14 cases of adenomyomatosis, and seven adenomas. Among the seven gallbladder adenomas, six were diagnosed as tubular adenoma while one was characterized as a papillary adenoma. No evidence of intramucosal carcinoma was present in any of the adenoma cases. All cases of benign disease were treated by simple cholecystectomy.

Tissue specimens were fixed in $10 \%$ formalin and embedded in paraffin wax. Representative blocks including the greatest dimension of the tumour were selected; $4 \mu \mathrm{m}$-thick serial sections were examined by immunohistochemistry.

\section{Immunohistochemistry}

Immunohistochemical reactions were performed using the streptavidin-biotin-peroxidase method. The mouse monoclonal primary antibodies used were anti-human CD4, anti-human CD8 (pre-diluted, Nichirei Corporation, Tokyo, Japan), anti-human CD57 (Leu 7, Becton Dickinson Immunocytometry System, San Jose, CA, USA) at a dilution of $1: 5$, and anti S-100 protein (DAKO, Glostrup, Denmark) at a dilution of $1: 2000$. CD57 identifies cells originating from the neural crest, including NKCs (Sangueza and Requena, 1998; Ishigami et al, 2000a, b), while S-100 protein is an adequate marker of DCs (Lespagnard et al, 1999; Ishigami et al, $2000 \mathrm{a})$. As positive controls, the normal adenoid tissue, prostate gland and nerve fibre were stained for CD4 and CD8, CD57, and S100 protein, respectively. Sections were deparaffinised in xylene, washed in phosphate-buffered saline (PBS, $\mathrm{pH} 7.4$ ), and rehydrated through a graded series of ethanol solutions. For CD4 and CD8 immunohistochemistry, following treatment with sodium citrate buffer (Ventana-Bio Tek Solutions, Tucson, AZ, USA), specimens were subjected to autoclave heat for $20 \mathrm{~min}$, and to microwave heat for $20 \mathrm{~min}$, respectively. Endogenous peroxidase activity was blocked by a $10 \mathrm{~min}$ incubation with $3 \%$ hydrogen peroxide methanol. Following washing in PBS, specimens were saturated with $10 \%$ normal goat serum (Histofine SAB-PO kit, Nichirei
Corporation, Tokyo, Japan) for $5 \mathrm{~min}$, then incubated at room temperature for $30 \mathrm{~min}$ with primary antibody. After washing in PBS, a biotinylated goat anti-mouse immunoglobulin antibody (Histofine SAB-PO kit, Nichirei Corporation, Tokyo, Japan) was applied during a $60 \mathrm{~min}$ incubation at room temperature. Immunohistochemical reactions were visualised with freshly prepared 3,3'-diamino-benzidine tetrahydrochloride (Histofine SAB-PO kit, Nichirei Corporation, Tokyo, Japan). Slides were counterstained with haematoxylin and mounted on coverslips. Immunostained sections were evaluated under a microscope (Olympus, Japan).

\section{Quantification methods}

The degree of immune cell infiltration was observed in more than 10 independent high-power $(\times 200)$ microscopic fields $(\mathrm{HPF})$ for each tissue sample. The three areas with the most abundant distribution were selected.

$\mathrm{CD}^{+}$and $\mathrm{CD}^{+} \mathrm{T}$ cells were quantified as described (Naito et al, 1998), with the following modifications. An average of more than 50 per three HPF accumulating $\mathrm{CD}^{+}$or $\mathrm{CD} 8^{+}$TILs were designated as infiltration. Individual cases were classified into high, low or no CD4 ${ }^{+}$or CD8 ${ }^{+}$TIL infiltration based on location and quantitation. The high group possessed immunoreactive $\mathrm{T}$ cells in the epithelial component of the tumour, either accumulating within the cancer cell nests and complexes or found predominantly in the mesenchymal stroma surrounding the epithelial component of the tumour. The low group exhibited immunoreactive $\mathrm{T}$ cells sparse, evenly distributed $\mathrm{CD} 4^{+}$or $\mathrm{CD} 8{ }^{+}$ TILs between the epithelial and stromal components and/or along the invasive margin of the tumour. The negative group did not demonstrate any immunoreactive $\mathrm{T}$ cells in either the epithelial and stromal components or along the invasive margin of the tumour.

Natural killer cells and DCs were quantified according to the method of Ishigami et al (2000a). In intratumoral fields, 10 or more NKCs per $10 \mathrm{HPF}$ were defined as possessing high NKC infiltration, while less than $10 \mathrm{NKCs}$ per $10 \mathrm{HPF}$ were designated as low NKC infiltration. A total of 20 or more DCs per HPF were defined as high DC infiltration; less than 20 DCs per HPF characterised low DC infiltration.

In benign diseases, immunoreactive cells within and surrounding the epithelial lesion were quantitated.

The degree of immune cell infiltration for each section was represented by the median of scores evaluated by three investigators. All specimens were evaluated without any previous knowledge of the patients' clinical background.

\section{Statistical analysis}

The $\chi^{2}$ test and Fisher's exact test were employed when appropriate. The Kaplan-Meier method was used to estimate the overall survival. Survival differences were analysed by the log-rank test, based on the status of immune cell infiltration. Univariate analyses of immune cell infiltration and clinicopathological features were performed using the Cox proportional hazards model. Probability $(P)$ values of less than 0.05 were regarded as significant in all the analyses. Statistical analyses were performed using statistical software (StatView J version 5.0; Abacus Concepts Inc.).

\section{RESULTS}

\section{Immunohistochemistry for immune cells}

$\mathrm{CD}^{+} \mathrm{T}$ cells were distributed mainly along the invasive margin and in the cancer stroma. Of the total cancer cases, $51.1 \%$ (23 out of 45 ) were recognised as possessing high $\mathrm{CD}^{+}$ 
$\mathrm{T}$ cell infiltration. In seven cases, TILs were identified within cancer cell nests (Figure 1A). CD8 ${ }^{+} \mathrm{T}$ cells were also distributed along the invasive margin and within the cancer stroma; $37.8 \%$ (17 out of 45) possessed high $\mathrm{CD}^{+}{ }^{+} \mathrm{T}$ cell infiltration. In 10 cases, TILs were found within cancer cell nests (Figure 1B). NKC infiltration varied from 0 to $7.3 / \mathrm{HPF}$ (average 1.2); $33.3 \%$ of the total cases (15 out of 45) contained high NKC infiltration. NKCs diffusely infiltrated the cancerous lesions (Figure 1C). DC infiltration varied from 0 to $88 / \mathrm{HPF}$ (average 22.8), with $48.9 \%$ (22 out of 45 ) exhibiting high DC infiltration. DCs were also observed diffusely throughout the lesions (Figure 1D).

In cases of benign disease, little or no infiltration of any kind of immune cells were observed (Figure 2).
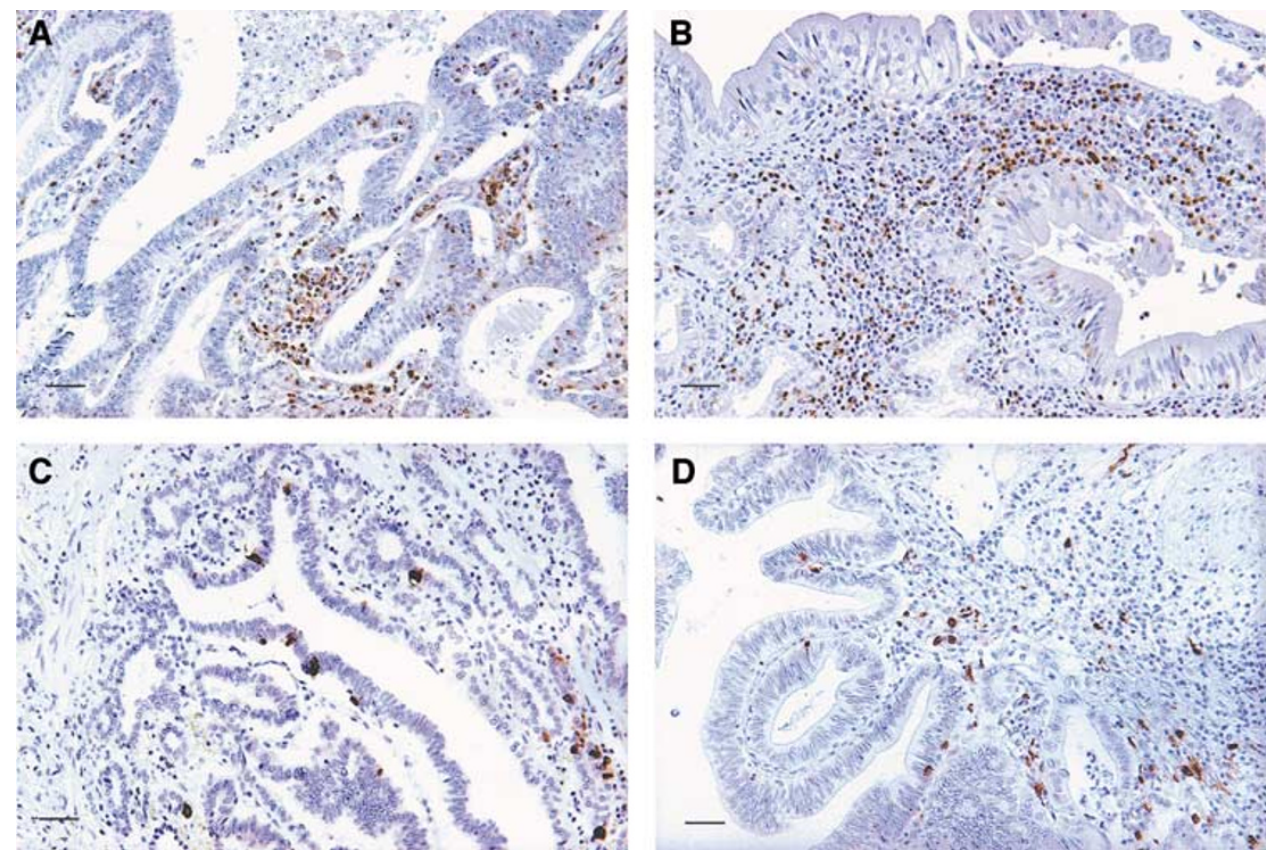

Figure I Representative photomicrographs of immunohistochemical staining of immune cells within gallbladder cancer (scale bar, $40 \mu \mathrm{m})$. (A) high $\mathrm{CD}^{+}{ }^{+}$TILs; (B) high CD8 ${ }^{+}$TILs; (C) high NKC infiltration; (D) high DC infiltration.
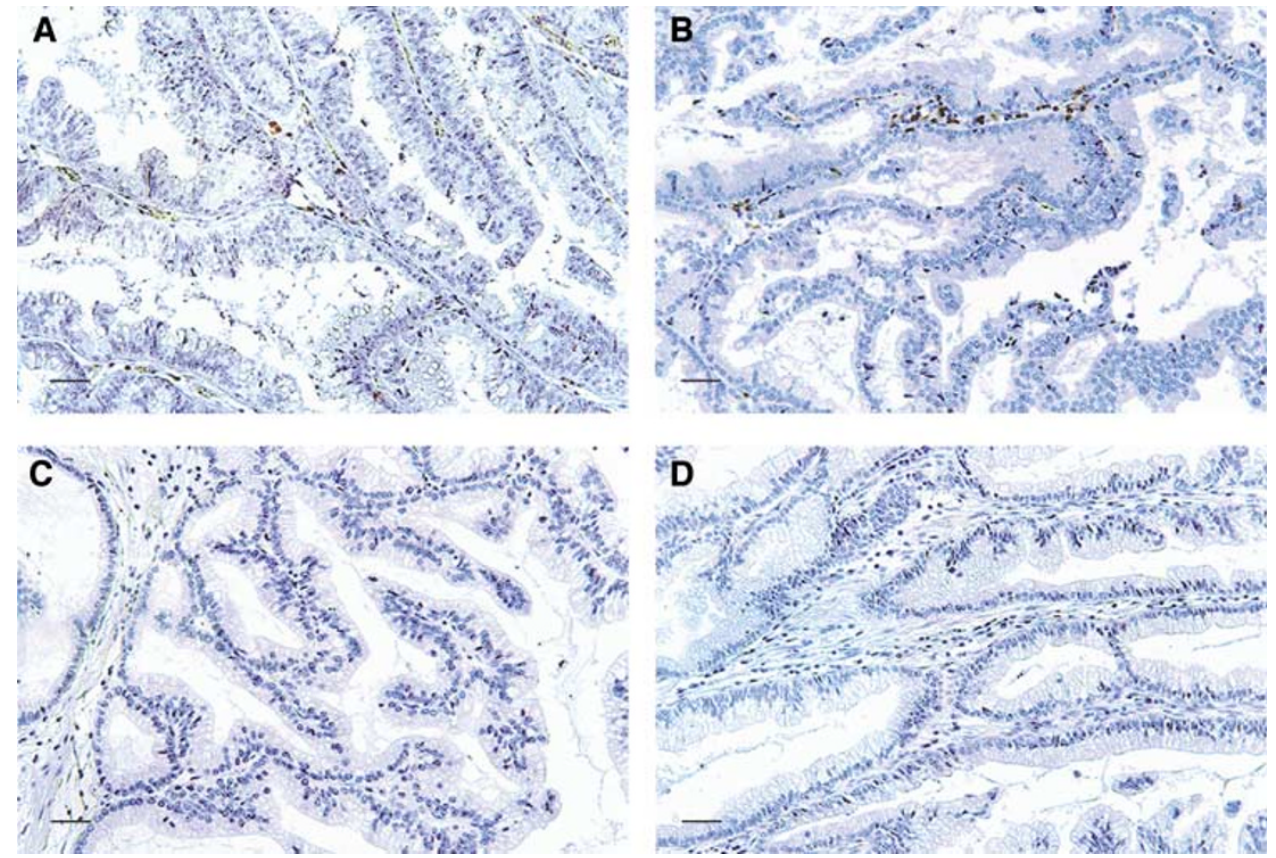

Figure 2 Representative photomicrographs of immunohistochemical staining of immune cells in adenomas of the gallbladder (scale bar, $40 \mu \mathrm{m}$ ). (A) adenoma stained for CD4; (B) adenoma stained for CD8; (C) adenoma stained for CD57; (D) adenoma stained for S-I 00 protein. 
Table I High level infiltration of immune cells and histopathological findings in gallbladder cancer

\begin{tabular}{|c|c|c|c|c|}
\hline Variables & High CD4 ${ }^{+}$TILs (\%) & High CD8 ${ }^{+}$TILs (\%) & High NKC infiltration (\%) & High DC infiltration (\%) \\
\hline \multicolumn{5}{|l|}{ Depth of invasion } \\
\hline pTI $(n=9)$ & $5(55.6)$ & $5(55.6)$ & $3(33.3)$ & $6(66.7)$ \\
\hline pT4 $(n=5)$ & I (20.0) & $0(0.0)$ & I (20.0) & $2(40.0)$ \\
\hline \multicolumn{5}{|c|}{ Lymph node metastasis } \\
\hline $\mathrm{pN} 2(n=12)$ & $4(33.3)$ & $6(50.0)$ & $3(25.0)$ & $4(33.3)$ \\
\hline \multicolumn{5}{|c|}{ Histopathological grading } \\
\hline GI $(n=27)$ & $12(44.4)$ & $17(63.0)$ & $9(33.3)$ & $16(59.3)$ \\
\hline$G 2(n=15)$ & $3(33.3)$ & $4(26.7)$ & $6(40.0)$ & $4(26.7)$ \\
\hline G3 $(n=3)$ & $2(66.7)$ & $2(66.7)$ & $0(0.0)$ & $2(66.7)$ \\
\hline \multicolumn{5}{|l|}{ P-stage grouping } \\
\hline
\end{tabular}

TILs = tumour-infiltrating lymphocytes; NKC = natural killer cell; DC = dendritic cell.

Table 2 Correlation between immune cells and clinicopathological features

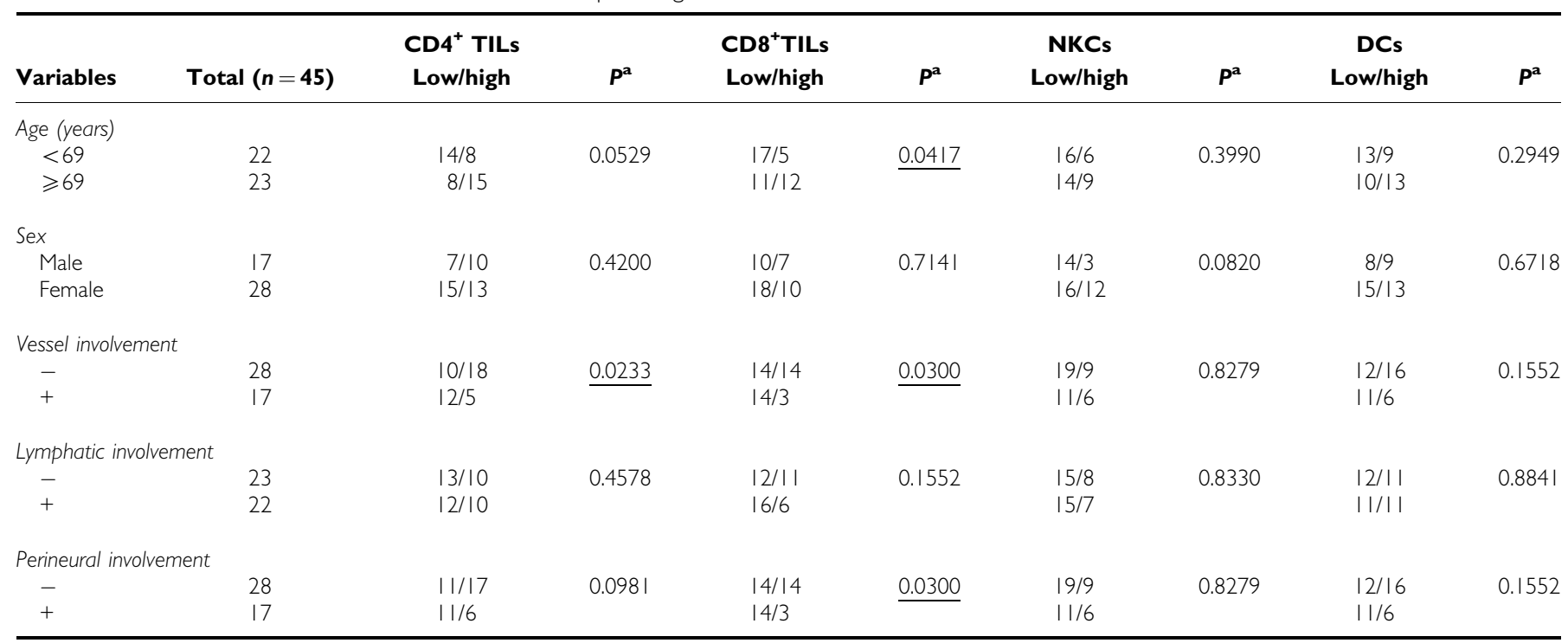

${ }^{a} \chi^{2}$ test. TILs = tumour-infiltrating lymphocytes; NKCs = natural killer cells; DCs = dendritic cells. The underlined numbers = significant.

\section{Immune cell infiltration and clinicopathological significance}

For the 45 patients with gallbladder cancer, we acquired pathological data on TNM classification, differentiation, vessel involvement, lymphatic involvement, perineural involvement, and stage grouping. Follow-up and clinical data were also obtained for all 45 patients. All cases of cancer evaluated in this study were diagnosed as adenocarcinomas. The details of high-level infiltration of immune cells and $\mathrm{pT}, \mathrm{pN}, \mathrm{G}$ categories, and p-stage grouping are indicated in Table 1 . No cases of pM1 were identified. The quantity of infiltrating $\mathrm{CD} 4{ }^{+}$TILs correlated with vessel involvement, pT category, and stage grouping. The number of intratumoral $\mathrm{CD}^{+}{ }^{+}$TILs correlated with age, vessel involvement, perineural involvement, and pT category. DC infiltration also correlated with $\mathrm{pN}$ category and stage grouping. NKC infiltration did not demonstrate any significant correlations with any of the examined clinicopathological factors (Tables 2, 3). Additionally, the strong correlation between TILs and depth of invasion is suggested in Table 1.

\section{Relationship among immunological factors}

The number of infiltrating $\mathrm{CD}^{+}{ }^{+}$cells also correlated with $\mathrm{CD} 8{ }^{+}$ TILs and DC infiltration (Table 4). There was no correlation, however, between the numbers of $\mathrm{CD} 8{ }^{+}$TILs and DC infiltration $(P=0.2989)$. NKC infiltration did not correlate with any other immunological factors. 
Table 3 Correlation between immune cells and TNM classification, tumour differentiation, and stage grouping

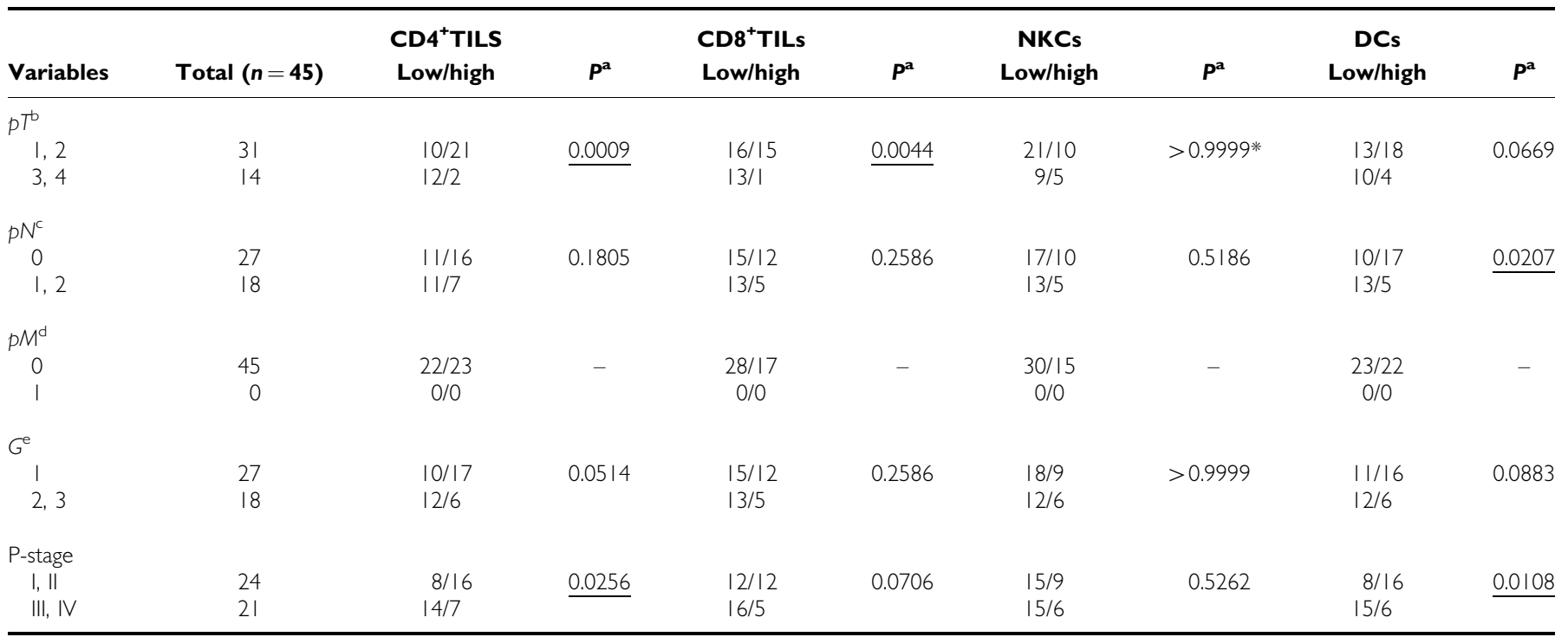

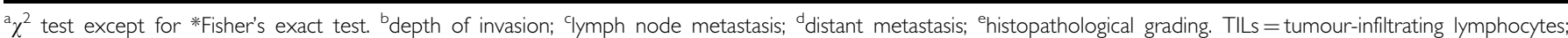
$\mathrm{NKCs}=$ natural killer cells; DCs = dendritic cells. The underlined numbers $=$ significant.

Table 4 Correlation among immune cells

\begin{tabular}{lccccc}
\hline Variables & Total $(\boldsymbol{n}=\mathbf{4 5})$ & $\begin{array}{c}\text { CD8 }{ }^{+} \text {TILs } \\
\text { Low/high }\end{array}$ & $\boldsymbol{P}^{\mathbf{a}}$ & $\begin{array}{c}\text { DCs } \\
\text { Low/high }\end{array}$ & $\boldsymbol{P}^{\mathbf{a}}$ \\
\hline $\begin{array}{l}\text { CD4 }{ }^{+} \text {TILs } \\
\text { Low }\end{array}$ & 22 & $19 / 3$ & 0.0011 & $17 / 5$ & 0.0006 \\
High & 23 & $9 / 14$ & & $6 / 17$ & \\
\hline
\end{tabular}

${ }^{a} \chi^{2}$ test. TILs $=$ tumour-infiltrating lymphocytes; $\mathrm{DCs}=$ dendritic cells.
A

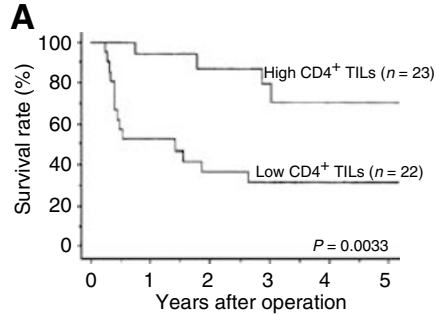

C

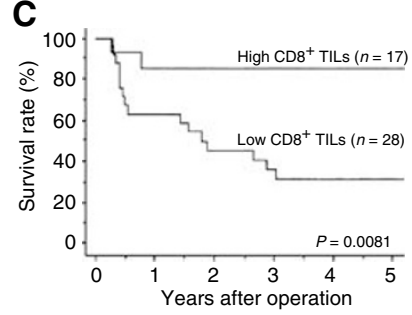

B

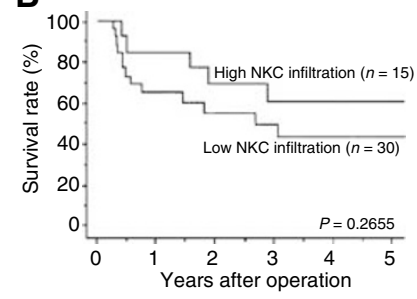

D

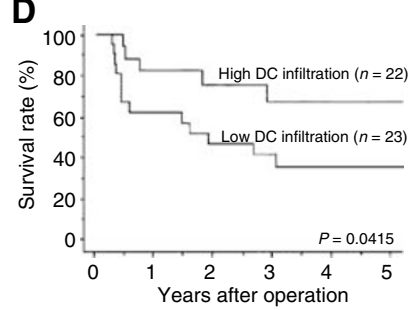

Figure 3 Kaplan-Meier analyses of the overall survival of gallbladder cancer patients with either a low or high level of immune cell infiltration. Pvalues were determined by the log-rank test. $(\mathbf{A}) \mathrm{CD}^{+}{ }^{+} \mathrm{TILs}$; (B) CD8 ${ }^{+}$ TILs; (C) NKC infiltration; (D) DC infiltration.

\section{Correlation with survival}

Using Kaplan-Meier actuarial analysis, the overall survival for patients possessing high numbers of $\mathrm{CD} 4{ }^{+}$TILs, CD8 ${ }^{+}$TILs, and
Table 5 Univariate analyses with Cox's proportional hazards model for imuune cells and clinicopathological features in all 45 patients

\begin{tabular}{lccr}
\hline & \multicolumn{3}{c}{ Univariate } \\
\cline { 2 - 4 } Variables & Hazards ratio & $\mathbf{9 5 \%} \mathbf{~ C l}^{\mathbf{a}}$ & \multicolumn{1}{c}{$\boldsymbol{P}^{\mathbf{b}}$} \\
\hline CD4 $^{+}$TILs & 0.218 & $0.071-0.666$ & 0.0075 \\
CD8 ${ }^{+}$TILs & 0.173 & $0.040-0.753$ & 0.0194 \\
NKCs & 0.560 & $0.199-1.579$ & 0.2727 \\
DCs & 0.358 & $0.128-1.006$ & 0.0513 \\
Age & 0.215 & $0.076-0.609$ & 0.0038 \\
Sex & 1.491 & $0.589-3.772$ & 0.3990 \\
PT & 24.296 & $6.466-91.301$ & $<0.0001$ \\
PN & 9.651 & $3.499-26.619$ & $<0.0001$ \\
G & 5.419 & $1.989-14.760$ & 0.0009 \\
ly & 5.518 & $2.022-15.060$ & 0.0009 \\
V & 5.807 & $2.185-15.430$ & 0.0004 \\
Ppn & 4.733 & $1.831-12.237$ & 0.0013 \\
\hline
\end{tabular}

${ }^{\mathrm{a}} \mathrm{Cl}=$ confidence interval; ${ }^{\mathrm{b}}$ from $\mathrm{Cox}$ regression test. TILs tumour-infiltrating lymphocytes; $N K C s=$ natural killer cells; $D C s=$ dendritic cells. ly=lymphatic involvement; $\vee=$ vessel involvement; $\mathrm{ppn}=$ perineural involvement.

infiltrating DCs was significantly better than in exhibiting low infiltration (Figure 3A, B, and D). NKC infiltration did not correlate with survival (Figure 3C).

The numbers of $\mathrm{CD}^{+}$and $\mathrm{CD}^{+}$TILs, age, pT category, pN category, G category, vessel involvement, lymphatic involvement, and perineural involvement were identified by Cox univariate regression analysis as significant prognostic predictors (Table 5).

\section{DISCUSSION}

In gallbladder cancer, lymph-node metastases and depth of invasion of the primary tumour significantly affect patient outcome after surgery (Tsukada et al, 1997). Strong correlations between these pathological factors and the numbers of infiltrating immune cells suggest that the antitumour immune response may influence the prognosis of patients with gallbladder cancer in this 
study. The log-rank test revealed that high CD4 ${ }^{+}$TILs, high CD8 ${ }^{+}$ TILs, and high DC infiltration are each individual favourable prognostic predictors.

Tumour-associated antigens (TAA) can be recognised by $\mathrm{CD} 8{ }^{+}$ $\mathrm{T}$ cells in the context of MHC class I-expressing tumours (Schumacher et al, 2001). Overall immune responses, however, were too weak and transient to eradicate cancer cells in the majority of patients receiving immunisation (Wang, 2001). Therefore, growing attention has been paid to the value of $\mathrm{CD}^{+}{ }^{+}$T cells (Mumberg et al, 1999; Marzo et al, 2000; Beatty and Paterson, 2001; Wang, 2001) and DCs (Lespagnard et al, 1999; Almand et al, 2000) in antitumour immunity.

The correlation between DC infiltration and lymph-node metastasis observed in the present study conforms to the theory reported by Lespagnard et al (1999). Moreover, significant correlations were observed between $\mathrm{CD} 4{ }^{+}$and $\mathrm{CD}^{+}{ }^{+} \mathrm{T}$ cells and $\mathrm{CD}_{4}{ }^{+} \mathrm{T}$ cells and DCs. These results support the mechanism of immune activation reported by Larsson et al (2001).

Compared with benign diseases, high levels of infiltrating CD4 ${ }^{+}$ and CD8 ${ }^{+} \mathrm{T}$ cells and DCs were observed in cancer specimens. This outcome provides evidence that these immune cells possess cancer-specific activities in gallbladder cancer.

\section{REFERENCES}

Almand B, Resser JR, Lindman B, Nadaf S, Clark JI, Kwon ED, Carbone DP, Gabrilovich DI (2000) Clinical significance of defective dendritic cell differentiation in cancer. Clin Cancer Res 6: 1755-1766

Barnea E, Beer I, Patoka R, Ziv T, Kessler O, Tzehoval E, Eisenbach L, Zavazava N, Admon A (2002) Analysis of endogenous peptides bound by soluble MHC class I molecules: a novel approach for identifying tumorspecific antigens. Eur J Immunol 32: 213-222

Beatty GL, Paterson Y (2001) IFN-gamma-dependent inhibition of tumor angiogenesis by tumor-infiltrating $\mathrm{CD}^{+} \mathrm{T}$ cells requires tumor responsiveness to IFN-gamma. J Immunol 166: 2276-2282

Boon T, Cerottini JC, Van den Eynde B, Van der Bruggen P, Van Pel A (1994) Tumor antigens recognized by T lymphocytes. Annu Rev Immunol 12: 337 - 365

Brandle D, Brasseur F, Weynants P, Boon T, Van den Eynde B (1996) A mutated HLA-A2 molecule recognized by autologous cytotoxic T lymphocytes on a human renal cell carcinoma. J Exp Med 183: 2501 2508

Cooper MA, Fehniger TA, Caligiuri MA (2001) The biology of human natural killer-cell subsets. Trends Immunol 22: 633-640

Cubertafond P, Gainnant A, Cucchiaro G (1994) Surgical treatment of 724 carcinomas of the gallbladder. Results of the French Surgical Association Surgery. Ann Surg 219: $275-280$

Dhodapkar KM, Krasovsky J, Williamson B, Dhodapkar MV (2002) Antitumor monoclonal antibodies enhance cross-presentation of cellular antigens and the generation of myeloma-specific killer $\mathrm{T}$ cells by dendritic cells. J Exp Med 195: 125 - 133

Donohue JH, Nagorney DM, Grant CS, Tsushima K, Ilstrup DM, Adson MN (1990) Carcinoma of the gallbladder. Does radical resection improve outcome? Arch Surg 125: $237-241$

Gall FP, Kockerling F, Scheele J, Schneider C, Hohenberger W (1991) Radical operations for carcinoma of the gallbladder: present status in Germany. World J Surg 15: 328-336

Hui AM, Li X, Shi YZ, Takayama T, Torzilli G, Makuuchi M (2000) Cyclin D1 overexpression is a critical event in gallbladder carcinogenesis and independently predicts decreased survival for patients with gallbladder carcinoma. Clin Cancer Res 6: $4272-4277$

International Union Against Cancer (1997) TNM Classification of Malignant Tumours. Fifth Edition: 54-58

Ishigami S, Natsugoe S, Tokuda K, Nakajo A, Che X, Iwashige H, Aridome K, Hokita S, Aikou T (2000a) Clinical impact of intratumoral natural killer cell and dendritic cell infiltration in gastric cancer. Cancer Lett 159: $103-108$

Ishigami S, Natsugoe S, Tokuda K, Nakajo A, Che X, Iwashige H, Aridome K, Hokita S, Aikou T (2000b) Prognostic value of intratumoral natural killer cells in gastric carcinoma. Cancer 88: $577-583$
As NKCs were frequently identified in cancer specimens and not in benign diseases, NKC may have an ability to recognise cancer cells. NKC infiltration, however, did not correlate with either tumour progression or prognosis in this study. NKCs, constituting only a small portion of the tumour-infiltrating lymphocytes (Ishigami et al, 2000b), are components of the innate immune system capable of lysing target cells without prior sensitization (Cooper et al, 2001). Thus, the inability of NKCs to influence the outcome of disease may depend on the low proportion of total cells and weak anticancer specificity of NKCs.

We conclude as follows. Though the prognosis associated with TILs is not always good, $\mathrm{CD} 4^{+}$and $\mathrm{CD} 8^{+}$TILs and intratumoural DC infiltration, rather than NKCs, correlate with tumour progression, possibly serving as good prognostic predictors in patients with adenocarcinoma of the gallbladder.

\section{ACKNOWLEDGEMENTS}

We would like to thank Dr Toshiya Shinohara for helpful support in pathological investigation, and Mr Hiraku Shida and Ms Akiko Yagi for technical support in immunohistochemistry.

Kawamoto T, Shoda J, Irimura T, Miyahara N, Furukawa M, Ueda T, Asano T, Kano M, Koike N, Fukao K, Tanaka N, Todoroki T (2001) Expression of MUC1 mucins in the subserosal layer correlates with postsurgical prognosis of pathological tumor stage 2 carcinoma of the gallbladder. Clin Cancer Res 7: $1333-1342$

Knuth A, Wolfel T, Klehmann E, Boon T, Meyer zum Buschenfelde KH (1989) Cytolytic T-cell clones against an autologous human melanoma: specificity study and definition of three antigens by immunoselection. Proc Natl Acad Sci USA 86: 2804-2808

Larsson M, Fonteneau JF, Bhardwaj N (2001) Dendritic cells resurrect antigens from dead cells. Trends Immunol 22: 141-148

Lespagnard L, Gancberg D, Rouas G, Leclercq G, de Saint-Aubain Somerhausen N, Di Leo A, Piccart M, Verhest A, Larsimont D (1999) Tumor-infiltrating dendritic cells in adenocarcinomas of the breast: a study of 143 neoplasms with a correlation to usual prognostic factors and to clinical outcome. Int J Cancer 84: 309-314

Malone CC, Schiltz PM, Mackintosh AD, Beutel LD, Heinemann FS, Dillman RO (2001) Characterization of human tumor-infiltrating lymphocytes expanded in hollow-fiber bioreactors for immunotherapy of cancer. Cancer Biother Radiopharm 16: $381-390$

Marzo AL, Kinnear BF, Lake RA, Frelinger JJ, Collins EJ, Robinson BWS, Scott B (2000) Tumor-specific CD4 ${ }^{+} \mathrm{T}$ cells have a major 'post-licensing' role in CTL mediated anti-tumor immunity. J Immunol 165: 6047-6055

Mumberg D, Monach PA, Wanderling S, Philip M, Toledano AY, Schreiber $\mathrm{RD}$, Schreiber H (1999) $\mathrm{CD}^{+} \mathrm{T}$ cells eliminate MHC class II-negative cancer cells in vivo by indirect effects of IFN-gamma. Proc Natl Acad Sci USA 96: $8633-8638$

Naito Y, Saito K, Shibata K, Ohuchi A, Saigenji K, Nagura H, Ohtani H (1998) $\mathrm{CD}^{+} \mathrm{T}$ cells infiltrated within cancer cell nests as a prognostic factor in human colorectal cancer. Cancer Res 58: $3491-3494$

Nakano O, Sato M, Naito Y, Suzuki K, Orikasa S, Aizawa M, Suzuki Y, Shintaku I, Nagura H, Ohtani H (2001) Proliferative activity of intratumoral $\mathrm{CD}^{+}$T-lymphocytes as a prognostic factor in human renal cell carcinoma: clinicopathologic demonstration of antitumor immunity. Cancer Res 61: 5132-5136

Oertli D, Herzog U, Tondelli P (1993) Primary carcinoma of the gallbladder: operative experience during a 16-year period. Eur J Surg 159: 415-420

Quan ZW, Wu K, Wang J, Shi W, Zhang Z, Merrell RC (2001) Association of p53, p16, and vascular endothelial growth factor protein expressions with the prognosis and metastasis of gallbladder cancer. J Am Coll Surg 193: $380-383$

Ruckert JCR, Ruckert RI, Gellert K, Hecker K, Muller JM (1996) Surgery for carcinoma of the gallbladder. Hepatogastroenterology 43: 527-533

Sangueza OP, Requena L (1998) Neoplasms with neural differentiation: a review. Part II: malignant neoplasms. Am J Dermatopathol 20: 89-102 
Schumacher K, Wolfgang H, Roefzaad C, Schlag PM (2001) Prognostic significance of activated $\mathrm{CD}^{+} \mathrm{T}$ cell infiltrations within esophageal carcinomas. Cancer Res 61: 3932-3936

Shi YZ, Hui AM, Li X, Takayama T, Makuuchi M (2000) Over expression of retinoblastoma protein predicts decreased survival and correlates with loss of $\mathrm{p} 16^{\mathrm{INK} 4}$ protein in gallbladder carcinomas. Clin Cancer Res 6: 4096-4100

Sugawara Y, Makuuchi M, Hrihara Y, Noie T, Inoue K, Kubota K, Takayama T (1999) Tumor angiogenesis in gallbladder carcinoma. Hepatogastroenterology 46: 1682-1686

Tanaka F, Abe M, Akiyoshi T, Nomura T, Sugimachi K, Kishimoto T, Suzuki T, Okada M (1997) The anti-human tumor effect and generation of human cytotoxic $\mathrm{T}$ cells in SCID mice given human peripheral blood lymphocytes by the in vivo transfer of the Interleukin- 6 gene using adenovirus vector. Cancer Res 57: 1335-1343

Tsukada K, Kurosaki I, Uchida K, Shirai Y, Oohashi Y, Yokoyama N, Watanabe H, Hatakeyama K (1997) Lymph node spread from carcinoma of the gallbladder. Cancer 80: 661-667
Valone FH, Small E, MacKenzie M, Burch P, Lacy M, Peshwa MV, Laus R (2001) Dendritic cell-based treatment of cancer: closing in on a cellular therapy. Cancer J 7(Suppl 2): S53-S61

Van den Eynde B, Hainaut P, Herin M, Knuth A, Lemoine C, Weynants P, van der Bruggen P, Fauchet R, Boon T (1989) Presence on a human melanoma of multiple antigens recognized by autologous CTL. Int $J$ Cancer 44: 634-640

Wang RF (2001) The role of MHC class II-restricted tumor antigens and $\mathrm{CD}^{+} \mathrm{T}$ cells in antitumor immunity. Trends Immunol 22: $269-276$

Whiteside TL, Herberman RB (1995) The role of natural killer cells in immune surveillance of cancer. Curr Opin Immunol 7: 704-710

Wortzel RD, Philipps C, Schreiber H (1983) Multiple tumour-specific antigens expressed on a single tumour cell. Nature 304: 165-167

Ying H, Zeng G, Black KL (2001) Innovative cancer vaccine strategies based on the identification of tumour-associated antigens. Biodrugs 15: $819-831$ 